\title{
Brief Analysis on Innovation of Impromptu Piano Accompaniment Teaching in Colleges and Universities
}

\author{
Yi Ji \\ School of Music and Dance \\ Qujing Normal University \\ Qujing, Yunnan, China 655011
}

\begin{abstract}
Impromptu piano accompaniment, as a part of the piano teaching in colleges and universities, the course itself integrates piano playing skills and music theory knowledge, which not only comes up with higher requirements to the students, at the same time tests the teaching abilities of teachers. Teachers should teach music theory knowledge and piano playing skills, as well as cultivate the students' abilities of indentify staves and sounds in the classes.However, the teaching conditions of impromptu piano accompaniment in the actual teaching process bring people to the mire of worry. The hidebound teaching ideas and simple teaching methods of teachers directly damage the development of impromptu piano accompaniment in the colleges and universities in a large degree. Therefore, the most urgent action we must take for now is to carry out teaching reform of impromptu piano accompaniment in colleges and universities, so as to better assist students to foster the abilities of impromptu piano accompaniment. For this, the author of this paper combines the actual teaching experience, and analyzes the current situation of impromptu piano accompaniment teaching, so that comes up with detailed reform measures.
\end{abstract}

Keywords-ability cultivation; current situation of teaching; reform measures

\section{INTRODUCTION}

Since the social economic development improves the material standard of living of people, following which people are increasingly transferring more attentions to the spiritual pursuits and people have increasingly strict requirements towards art. Under such a circumstance, it requires more for the piano teaching in colleges and universities, that the piano talents should not only own excellent playing skills but have the abilities of impromptu piano accompaniment. The abilities of impromptu piano accompaniment refer to that the piano player does rely on the playing skills of self and music knowledge instead of the staves and improvise with matched sound textures without any preparation.This accompaniment method requires for high comprehensive quality of player. As the places for cultivating various talents, colleges and universities should accept the task of fostering the social demanded talents, and output piano playing talents meeting the require ments of the society. However, currently the impro mptu piano accompaniment teaching in colleges and universities of our country is not in a positive situation. Thus, the corresponding reform measures are necessary to be taken for improving the teaching and cultivating effects, so as to contribute strength for promoting the construction and development of socialist culture.

\section{VALUE OF IMPROMPTU PIANO ACCOMPANIMENT IN COLLEGES AND UNIVERSITIES}

\section{A. Express Free Imagination of Musical Creation}

The evaluation and judgment requirefor theoretical knowledge and practical experience of the piano accompanists to finally ensure that all kinds of music state can be created in accordance with the demands of musician's heart expression. In order to complete this process, players should have free imaginations on music creation and do not be limited to some frame where they cannot extricate from. Also only with creative free imagination, accompanists are able to lead to more powerful music works with strong artistic appeals, which will eventually be accepted and promoted by the public.In addition to the requirements of creating music works with visual and listening effects, players also are demanded to choose and determine appropriate tonality. What's more, during the process of choosing appropriate tonality, piano accompanis ts also need to have creative and free imag inations. Only when they are integrated into the music works, the singer and improvisational piano soundscan be better matched, so as to stimu late the singer's inner emotions and produce distinctive music image.

\section{B. Embody the Spiritual Freedom of Music Creation}

Impromptu accompaniment ability refers to the piano accompanists do not relies on staves and are in the absence of any preparation, on its own impromptu song or music playing skill and music knowledge to the missile and the sound texture. Impromptu accompaniment ability of improvisation, have higher request for the singer's ability, which can both embody the accompanist to master the ability of different songs, on the basis of the singer's emotional displays can also be flexible tonal vocabulary and transformation. The music works, can let the audience a full range of listening. 


\section{Evoke the Auditory Sense of Listener}

In the process of playing the music works, in order to render the music atmosphere to a certain degree, the piano impromptu accompaniment is required to foil singer with the piano melody track background and artistic conception. In the process of the whole play, performers will motivate the feelings of audienc through grasping the rhythm and musical instrument power, make the audience slowly melt in the process of music melody movement through visual infection, so as to ensure to arouse thedifferent emotional experience of audience.

\section{CURRENT SITUATION OF IMPROMPTU PIANO ACCOMPANIMENT TEACHING IN COLLEGES AND UNIVERSITIES}

Only a few people among graduates can master the piano playing skills. At present, the impromptu piano accompaniment teaching course opens only for a year. In the face of such rush time and multifarious piano playing skills of learning, we can woder how's the students' learning outcomes. In piano teaching techniques are different, playing a different style of song learning, but judging from the reaction of the broad masses of students, the difficulties in poor key learning outcomes; Impro mptu piano accompaniment brings together a variety of related subjects, it is a great test to performer integrated use of capacity. This is in the process of the original song writing again performers, test player creation ability, thinking activity and degree of adept piano technique. So, multi-tone music teaching has always been the key of the music teaching at universities. Also in the process of piano improvisation is a comprehensive process of many sided, so to learn foundation course of piano impromptu accompaniment is particularly important; currently widely exist in the process of music teaching in China teaching content is not reasonable, unreas onable curriculu m and time arrangement is unreasonable. In music teaching the connection between the sightsinging and ear practice and improvisation is generally ignored, and the related coursesare not arranged according to the actual situation. In addition, it is urgent to resolve the problem of serious unequal number of teachers and students. Therefore, colleges and universities should increase the construction of basic course, and reduce the influence to impromptu piano accompaniment caused by unfirm basic knowledge and skills.

\section{COUNTERMEASURES OF IMPROMPTU PIANO ACCOMPANIMENT TEACHING PROBLEMS IN COLLEGES AND UNIVERSITIES}

\section{A. Increase the Proportion of Piano Basic Practice}

Piano basic exercises include scales and arpeggios which are very important to piano learning, and without the abilities to support, to learn impromptu accompaniment is like building a castle in the air. But the students' attention to the piano basic comes from the necessity of practical application. Soduring teaching, the author adopts the method of a large number of demonstration to show you the basics in actual use, in order to cause the attention of the students, and the author will use the most widespread arpeggio to decorate to the students at the beginning of teaching, because the students have realized the importance of basic practice, complete basic exercises will not be a problem.

\section{B. Teach the Harmony Application Combining with Vocals}

The students are still staying in the degree of how to make a harmonic problem in learning process.pIn order to connect teaching content, It is necessary toturn the objects of harmonic orchestrationto vocal music works, in this way, students are able to learn the knowledge of the practical use. Let students through a lot of vocal music to analyze theory and practice together.

\section{Enforce the Sensitive and Comprehensive Abilities of Students towards Work}

Understanding of vocal music works on the whole grasp in the impromptu accompaniment is the most important, if not feeling good music will not make rational judg ment, cannot to allocate the appropriate accompaniment, so music feeling in music appreciation ability is more important. For example, the song of the Yangtze River the vocal music is a relatively great momentums, in writing, the rhythm is in a phrase, a hardhitting. So when choosing accompaniment figure can't break down the accompaniment form, choose a half of this will destroy the feeling of music in punchy, in this case to select column chord is more appropriate. During teaching, teachers can let students sense the difference between them by using the method of comparative demonstration. And like the sea, hometown, this piece of work is a lyrical narrative works, although is a three-beat of the music, but this piece has a distinctive lyricis $m$ and narrative, so should not only pay attention to the choices and accompaniment texture smooth, lyrical note also to music without destroying triple time feeling, it is difficult to grasp, triple meter if accompanied with pillar chords will fade music lyricism, if accompanied with arpeggios will weaken the three beat the feeling of music, so here with half decomposition accompaniment figure is more appropriate, half decomposition texture three-beat in rhythm to support to the music, the music has better performance on the ups and downs of the sea music image.

\section{MEASURES OF REFORMING IMPROMPTU PIANO} ACCOMPANIMENT TEACHING IN COLLEGES AND UNIVERSITIES

\section{A. Change Part of Teaching Ideas}

"Improvisation" is the key of piano impromptu accompaniment, whose teaching work differs from pianos performance teaching, besides requiring attention to imparting piano theoretical knowledge and playing skills, but also focusing on cultivating the students' sight-reading ability, ability of listening, strain capacity, etc.However, some of teachers in colleges and universities cannot grasp the purpose of impromptu piano accompaniment teaching and adhere to the traditional teaching concept to cultivate piano impromptu accompaniment talents by traditional teaching mode. They only attach importance to students' understanding andmastering of the piano skills, while ignoring to cultivate various abilities of students, which causes students only have superb performance skills, but are lack of high level of impromptu accompaniment. Therefore, teachers must change 
the traditional teaching concept and fundamentally change their indifferent attitude towards impromptu piano accompaniment, so that to correctly evaluate and understand the teaching task and teaching nature of piano impromptu accompaniment, eventually to straighten the position of impromptu piano accompaniment teaching. By that way, clarify the direction and specific goal and set up the target of training talents, strengthen the cultivation of students' impromptu orchestration abilities, so that they can become the real piano improvisational accompaniment talents for the society.

\section{B. Motivate Study Interests}

Since interest is the best teacher, according to this eternally immutable truth, teachers should motivate and cultivate the study interests of students by which to stimulate their enthusiasm of active creation and participation. Thereby, students are able to actively carry out various learning activities and grasp the initiative of learning in classes. Only by this way, students can genuinely participate in the learning activities and gain the opportunities of developing and solving problems, so that to improve their abilities. Therefore, teachers must stress on stimulating students' interests and make efforts to reduce the study pressure of students and evoke their enthusiasm to enable them to study more actively.

During the teaching process, teachers can motivate the interests of students for learning through describing the background of music. Since most practical music is strange for students during the impromptu piano accompaniment teaching, teachers may conduct detailed introduction on the music background to make students fully understand the creation intention of the compose, through which to motivate the interests of students for learning. Besides, teachers can also stimulate students'learning interests by creation practice. For example, during the teaching process, teachers can list some creation examples to cultivate the music aesthetic of students, eventually to fulfill the goal of stipulating students' learning interests. The following learning will become much simpler with interests.

\section{Reinforce the Construction o Teaching Staff in olleges and Universities}

The level of teaching staff of a college or university directly influences the teaching effects of various courses, so as the impromptu piano accompaniment courses. However, at present, the teaching of impromptu piano accompaniment is not been valued by part of colleges and universities. Mostly lack of piano teachers, or namely impromptu accompaniment teachers, the course are mainly taught by the teachers of piano or theory of composition courses, through they all have rich professional knowledge and strong skills, the task of teaching impro mptu piano accompaniment still cannot be taken by them due to some defects. Therefore, colleges and universities should reinforce the construction of teaching staff and cultivate and absorb a group of professional impromptu piano accompaniment teachers.On the one hand, colleges and universities should intensify the training for the existing impromptu piano accompaniment teachers. Since the courses of impromptu piano accompaniment in colleges and universities are mainly taught by the teachers of other related courses, colleges and universities must intensify their training for relevant knowledge and skills in order to enable them meet the more strict requirements of impromptu piano accompaniment teaching by various in-job training and learning, so as to assist them solve their problems and enhance the quality and abilities of each aspect. Eventually, they are capable of becoming professional impromptu piano accompaniment teachers. On the other hand, colleges and universities should absorb a group of professional impromptu piano accompaniment talents. Some of the qualified colleges and universities should take the absorption of impromptu piano accompaniment talents as the key to construct teaching staff by recruiting some talents who have strong specialized knowledge, professional, practical and theoretical abilities. By this way, not only the problem that adjunct teachers are not able to play a full ability to work on the relevant teaching activities due to large number of workload can be solved, but enable the improvement of impromptu piano accompaniment teaching to refresh its energies.

\section{Innovate the Classroom Teaching Method}

In the process of most traditional impromptu piano accompaniment teaching, the teachers conduct teaching activities mostly by the form of collective teaching, which has both advantages and disadvantages. That is, though it is easy to be conducted, students cannot obtain sufficient practice because of the limitation of teaching conditions, and the teaching effectsare badly affecteddue to the weak pertinence. Therefore, some reform is necessary to be put forward. The author thinks that a combination of collective lessons, group classes, and individual classes can be used for impromptu piano accompaniment teaching.

1) Collective teaching: Collective teaching, with its advantages of wide audiences and easy to conduct and be suitable to teach theoretical knowledge, generally is conducted in classrooms. However, there are still some disadvantages of it. Therefore, teachers should give full play to its advantages and avoid its disadvantages, to use this teaching formto focuson the imparting of knowledge.

2) Group teaching: Compared to collective teaching, group teaching has more flexible teaching mode and more obvious advantages. Mostly a group is formed by no more than ten students, all of which surround one (or more) piano and listen to the teachers' teaching and demonstration; after the completion of classroom teaching, the students can practice by themselves and carry out discussions. This teaching mode increases the interaction of teachers and students and provides abundant practice time so that it is a relatively effective teaching.

3) Individual teaching: This mode is rarely seen in colleges and universities, by which the teacher and the student carry out the teaching activity by one-to-one way with stronger pertinence and distinct teaching effects but few audiences and lots of class hours resulting of not being able to widely open. 


\section{E. Scientifically Set the Courses of Impromptu Piano Accompaniment Courses}

The subject characteristics should be taken in consideration when setting impromptu piano accompaniment courses. First, on the content, the learn of piano impromptu accompaniment lessonsneeds to be based on the related knowledge of vocal music and piano lessons, therefore, the courses should be set after students study the basic knowledge and skills of vocal music and piano. In addition, studying musical forms is helpful for students to grasp the overall structure of musicand master the musical forms, which provide the conditions for the reasonable arrangement of harmony and texture, so it is preferable to carry out the impromptu piano accompaniment coursesand music stylistic theory courses as well as musical formal courses simultaneously. Second, on the time; in view of the vocal music courses and piano coursesare the learning basis of impromptu piano accompaniment, thus, the impromptu piano coursesare best not to set in the freshman or sophomore but from the beginning of junior to graduation, and conduct impromptu piano accompaniment teaching courses for two school years.For the teaching time, one class hour of a week should be changed totwo hours for every week, and the class number should not be too muchwith seven to ten as appropriate.

\section{CONCLUSION}

The significance of impromptu piano accompaniment teaching becomes more and more obvious. Thus, the school should provide the students with various information resources and intensify the construction of modernization teaching methods to form a favorable environment for realizing the cultivation of students' abilities to collect and acquire knowledge. In addition, teachers should combine theories with actual life to enable the students to apply the acquired knowledge in actual practices and gain experience and lessons from failures. At the same time, constantly reform the existing teaching model and establish a new and suitable teaching model combining the actual demands in order to ensure the cultivation effects and provide the society with more excellent piano talents.

\section{REFERENCES}

[1] Wu Peng. Analysis on the Current Situation and Innovative Development of Impromptu Piano Accompaniment Teaching in Colleges and Universities[J].Popular Song. 2015 (11): 12.

[2] Mao YUjuan. Related Reflections on the Problems of Impromptu Piano Accompaniment Teaching in Colleges and Universities[J]. Northern Music. 2015 (18): 45.

[3] Zhang Xuanyu. Several Reflections on Impromptu Piano Accompaniment Teaching in Colleges and Universities[J].Contemporary Music. 2015 (09): 25-27.

[4] MengSinuo. Exploit and Innovation of Impromptu Piano AccompanimentTeaching [J]. Journal of Changchun Education College. 2015 (05): 67

[5] GuoWeimin. Several Reflections on Impromptu Piano Accompaniment Teaching in Colleges and Universities[J]. Music Space Time. 2014 (23): 58.

[6] TianJie. How to Innovate Impromptu Piano Accompaniment Teaching[J]. Notonly Music. 2014 (11): 112.
[7] Song Shuping. Exploration and Analysis on the Teaching Practice of Improving Impromptu Piano Accompaniment Ability[J]. Yellow River of the Song. 2015 (22): 78.

[8] NiuXimeng. Study on Impromptu Piano Accompaniment and the Cultivation of Impromptu Piano Accompaniment Ability[J]. Music Spacetime. $2016(02): 134$ 